$\underline{\text { Review Article }}$

\title{
RELAXIN: A MAGICAL THERAPY FOR HEALTHY HEART
}

\author{
AJAZ AHMAD WAZA', SHABIR AHMAD BHAT ${ }^{1}$, ZEENAT HAMID²
}

${ }^{1}$ Centre of Research for Development (CORD) University of Kashmir, Srinagar, Jammu and Kashmir, 190006, India, ${ }^{2}$ Department of Biotechnology, University of Kashmir, Srinagar, Jammu and Kashmir, (190006) India Email: ajazahmad09@gmail.com

Received: 20 Oct 2017, Revised and Accepted: 12 Dec 2017

\section{ABSTRACT}

Relaxin (a peptide hormone) has emerged as a cardio protective agent and plays a vital role in normal cardiac function. By activation a complex network of signalling cascade, relaxin is responsible for creating a healthy environment for heart functioning. Under pathological conditions, such as cardiomyopathy and heart failure, the expression level of relaxin is increased dramatically to protect the heart. By promoting angiogenesis, vasodilatation, improving ischemia/reperfusion injury and remodeling, relaxin has emerged as a magical agent to address cardiac abnormalities. Over the past 3 decades, various cardio protection strategies are in use to deal with cardiac diseases, however, till date, no effective therapy is in clinical practice. Relaxin has emerged as a novel therapeutic agent to have beneficial action during various pathological conditions. In this review, we have discussed different cardio protective roles of relaxin that marks it, as an effective agent to tackle heart-related diseases.

Keywords: Relaxin, Relaxin family peptide receptor 1, Serelaxin, Heart failure

(C) 2018 The Authors. Published by Innovare Academic Sciences Pvt Ltd. This is an open access article under the CC BY license (http://creativecommons.org/licenses/by/4.0/) DOI: http://dx.doi.org/10.22159/ijcpr.2018v10i1.24405

\section{INTRODUCTION}

Relaxin (6-kDa peptide) was discovered in 1926, as a hormone that influences the reproductive track of females. It has got 2 polypeptide chains (fig. 1), similar to insulin [1, 2]. In humans, three relaxin genes namely relaxin 1 gene, 2 and 3 have been identified and each of which encodes different relaxin peptides namely relaxin 1 (H1 relaxin), relaxin 2 (H2 relaxin) and relaxin 3 (H3 relaxin) respectively. During the review, the human relaxin 2 peptide will be simply referred as "relaxin" [3]. From last two decades tremendous research has been done to understand the structure and function of Relaxin peptide [4]. The receptor for relaxin is relaxin family peptide receptor (RXFP) 1 and consists of trans membrane domains with a large extracellular domain [5]. Binding of relaxin to RXFP1 activates a signal transduction pathway that send a signal to the inside of cell. It has been found that relaxin has various intracellular mechanisms of action and only few have been elucidated. Relaxin activates mitogen-activated protein kinase (MAPK) via phosphorylation of MAPK kinase [6, 7]. PI3K activation by relaxin has also been reported and works along with MAPK and results in the intracellular level of cAMP in a biphasic manner. Firstly relaxin acts via $\mathrm{Ga}_{\mathrm{s}}$ activation and later through $\mathrm{Ga}_{13}$ activation, which in turn releases G- $ß \gamma$ subunits and ultimately activates $\mathrm{PI} 3 \mathrm{~K}$ and protein kinase $\mathrm{C}$ (PKC)-mediated metabolic pathway [8] (fig. 2). PKC has been found to increase myofilament activity in the cardiac cells of female mice [9]. For understanding the signalling cascade associated with the relaxin, please refer to the fig. 1.

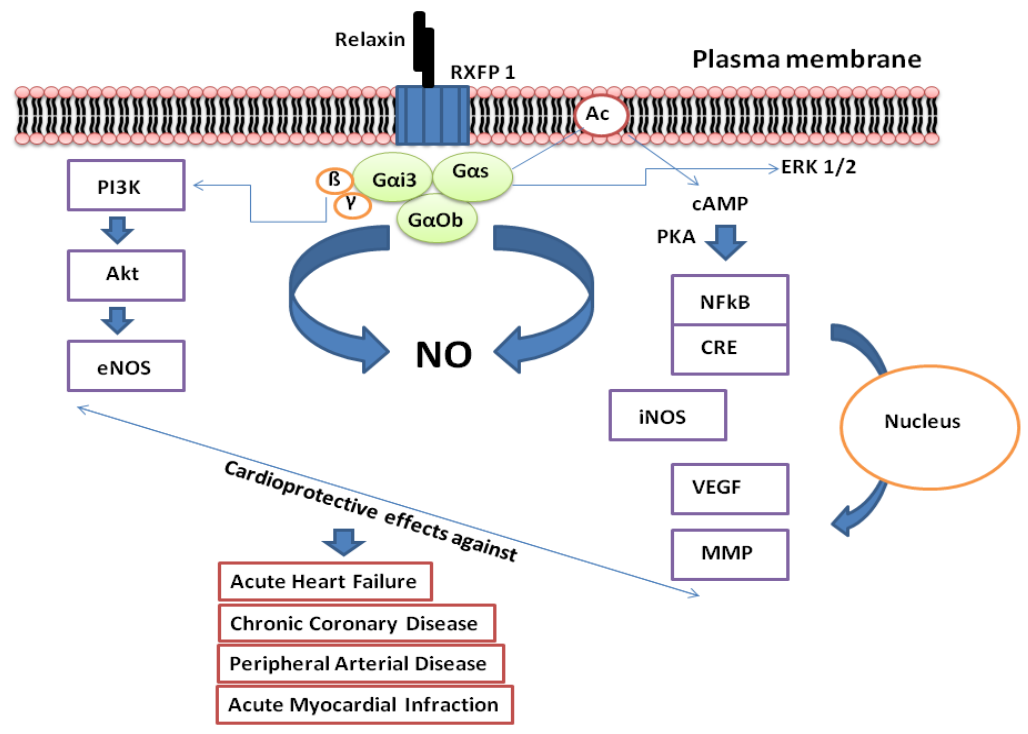

Fig. 1: Shows signaling cascade and mechanism of action of relaxin in the cardiovascular system: The combinatory effect of these cascades ultimately leads to anti-inflammatory, vasodilatation and antioxidant and actions as well as antifibrotic and angiogenesis effects. These effects are cardioprotective against different cardiac abnormalities like acute myocardial infarction, acute heart failure as well as chronic conditions like a chronic coronary disease, peripheral arterial disease and chronic heart failure. Abbreviations used in fig. 1 includes Akt (protein kinase B), Ac (adenylyl cyclase), cAMP (cyclic adenosine mono-phosphate, CRE (cAMP response element), eNOS (endothelial nitric

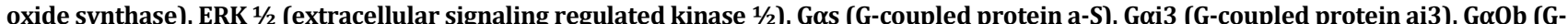
coupled protein $\alpha \mathrm{Ob}$ ), iNOS (inducible nitric oxide synthase), MMP (matrix metalloproteinase), NFkB (nuclear factor kB), NO (nitric oxide), PI3K (phosphatidylinositol 3 kinase), PKA (protein kinase A), RXFP1 (relaxin receptor-1) and VEGF (vascular endothelial growth factor). 
Relaxin has been found to protect the heart against various pathophysiological conditions (fig. 1). It exerts a positive, potent and dose-dependent chronotropic effect in the heart [10-12] and increases heart rate in the perfused intact heart [13-16]. In rat atria, relaxin produces greater cardioprotective effects than angiotensin II, adrenaline, endothelin-1, isoprenaline, serotonin or histamine [11]. One of the most important effects associated with relaxin is to stimulate secretion of atrial natriuretic peptide (regulate cardiovascular homeostasis) [16]. Recently, recombinant $\mathrm{H} 2$ relaxin treatment was able to protect the heart against the cardiac fibrosis in relaxin null mice [17], mice with cardiac-specific overexpressed b2-adrenergic receptors (such mice undergo heart failure and premature death) [17] and rats with spontaneously hypertension [18]. The beauty of the relaxin treatment is that it reduces cardiac fibrosis only in diseased chambers of the heart without affecting the normal myocardium tissue.

In normal cardiac tissue, relaxin level remains low but its level increases dramatically during various pathological conditions like heart failure and cardiomyopathy [19].

In another study, it was found that porcine relaxin is able to provide protection to the heart of guinea pigs and rats following ischaemiareperfusion-induced myocardial injury by maintaining coronary flow during ischaemia and increasing flow during reperfusion and by improving cardiac contractility $[20,21]$. Relaxin was found to reduce the ventricular arrhythmias and death, myocardial area damaged, lipid peroxidation of the plasma membrane, neutrophil invasion, calcium overload, activation of platelet and mast cells and myocardial cell injury in male rats [21]. Additionally, in rats pretreatment with relaxin has been found to be cardioprotective against cardiac anaphylaxis induced by ovalbumin (OVA) injection (increases histamine concentration, mast cell degranulation, chronotropy, inotropy and decreased coronary flow) [22]. There are now ample evidence to shows relaxin act on the heart by inhibiting collagen degradation and by increasing matrix metalloproteinase (MMP) expression via downregulation of fibroblast proliferation and differentiation [17]. Serelaxin (RLX030, Novartis) is recombinant human relaxin-2 with molecular formula as C256H408N74074S8 and a molecular weight of $5.96 \mathrm{kDa}$ [23]. The cardioprotective effects of relaxin have attracted interest in the use of serelaxin to treat heart failure.

\section{CONCLUSION}

Relaxin has emerged as a cardioprotective drug in several animal models due to its vasodilatory properties and pleiotropic effects. Recently, numerous clinical trials of relaxin in healthy individuals, as well as patients with acute heart failure, have placed it in a safer zone with little or no side effects. Recently, Serelaxin has emerged as a promising drug to treat acute heart failure patients. Putting together, it can be stated that understanding the molecular mechanism of relaxin action fully, will pay way to use it as a "magical drug" for healthy heart.

\section{ACKNOWLEDGEMENT}

Council of Scientific and Industrial Research (CSIR) and Science and Engineering Research Board (SERB) GOI, New Delhi are acknowledged for providing fellowship to Ajaz Ahmad Waza (CSIRRA fellow: No. 9/251 (0077)/2k17) and Shabir Ahmad Bhat (PDF/2016/003730) respectively.

\section{AUTHORS CONTRIBUTIONS}

All the author have contributed equally

\section{CONFLICT OF INTERESTS}

Declared none

\section{REFERENCES}

1. F Hisaw. Experimental relaxation of the pubic ligament of the guinea pig. Proc Soc Exp Biol Med 1926;23:661-3.
2. CD Sherwood, EM O'Byrne. Purification and characterization of porcine relaxin. Arch Biochem Biophysics 1974;160:185-96.

3. HM Bathgate RA, Van der Westhuizen ET, Callander GE, Kocan M, Summers RJ. Relaxin family peptides and their receptors. Physiol Rev 2013;93:405-80.

4. RAD Bathgate, Hsueh AJW, Sherwood OD. Physiology and molecular biology of the relaxin peptide family. In: JD Neill. Ed. Knobil and Neill's Physiology of Reproduction. 3rd edition; 2006b. p. 679-768.

5. SY Hsu. New insights into the evolution of the relaxin-LGR signaling system. Trends Endocrinol Metab 2003;14:303-9.

6. BC Dschietzig T, Richter C. Relaxin, a pregnancy hormone is a functional endothelin-1 antagonist: attenuation of endothelin-1mediated vasoconstriction by stimulation of endothelin type-B receptor expression via ERK-1/2 and nuclear factor-kappa B. Circ Res 2003;92:32-40.

7. Q Zhang, SH Liu, M Erikson, M Lewis, E Unemori. Relaxin activates the MAP kinase pathway in human endometrial stromal cells. J Cell Biochem 2002;85:536-44.

8. ML Halls, RA Bathgate, RJ Summers. Relaxin family peptide receptors RXFP1 and RXFP2 modulate cAMP signaling by distinct mechanisms. Mol Pharmacol 2006;70:214-26.

9. WP Shaw EE, Kulpa J. Relaxin alters cardiac myofilament function through a PKC-dependent pathway. Am J Physiol Heart Circ Physiol 2009;297:H29-H36.

10. DG Ward, GR Thomas, MJ Cronin. Relaxin increases rat heart rate by a direct action on the cardiac atrium. Biochem Biophys Res Commun 1992;186:999-1005.

11. H Kakouris, LW Eddie, RJ Summers. Cardiac effects of relaxin in rats. Lancet 1992;339:1076-8.

12. X Han, Y Habuchi, WR Giles. Relaxin increases heart rate by modulating calcium current in cardiac pacemaker cells. Circulation Res 1994;74:537-41.

13. YY Tan, Wade JD, Tregear GW, Summers RJ. Comparison of relaxin receptors in rat isolated atria and uterus by use of synthetic and native relaxin analogues. Br J Pharmacol 1998;123:762-70.

14. T Bani-Sacchi, M Bigazzi, D Bani, PF Mannaioni, E Masini. Relaxin-induced increased coronary flow through stimulation of nitric oxide production. Br J Pharmacol 1995;116:1589-94.

15. GR Thomas, R Vandlen. The purely chronotropic effects of relaxin in the rat isolated heart. J Pharm Pharmacol 1993;45:927-8.

16. $M$ Toth, $P$ Taskinen, $H$ Ruskoaho. Relaxin stimulates atrial natriuretic peptide secretion in perfused rat heart. J Endocrinol 1996;150:487-95.

17. CS Samuel, EN Unemori, I Mookerjee, RA Bathgate, SL Layfield, J Mak, et al. Relaxin modulates cardiac fibroblast proliferation, differentiation, and collagen production and reverses cardiac fibrosis in vivo. Endocrinology 2004;145:4125-33.

18. ED Lekgabe, $\mathrm{H}$ Kiriazis, $\mathrm{C}$ Zhao, $\mathrm{Q}$ Xu, XL Moore, Y Su, et al. Relaxin reverses cardiac and renal fibrosis in spontaneously hypertensive rats. Hypertension 2005;46:412-8.

19. RC Dschietzig T, Bartsch C, Laule M, Armbruster FP, Baumann G, Stangl K. The pregnancy hormone relaxin is a player in human heart failure. FASEB J 2001;15:2187-95.

20. E Masini, D Bani, MG Bello, M Bigazzi, PF Mannaioni, TB Sacchi. Relaxin counteracts myocardial damage induced by ischemiareperfusion in isolated guinea pig hearts: evidence for an involvement of nitric oxide. Endocrinology 1997;138:4713-20.

21. D Bani, E Masini, MG Bello, M Bigazzi, TB Sacchi. Relaxin protects against myocardial injury caused by ischemia and reperfusion in rat heart. Am J Pathol 1998;152:1367-76.

22. E Masini, G Zagli, JF Ndisang, M Solazzo, PF Mannaioni, D Bani. Protective effect of relaxin in cardiac anaphylaxis: involvement of the nitric oxide pathway. Br J Pharmacol 2002;137:337-44.

23. JR Teerlink, G Cotter, BA Davison, GM Felker, G Filippatos, BH Greenberg, et al. Serelaxin, recombinant human relaxin-2, for treatment of acute heart failure (RELAX-AHF): a randomised, placebo-controlled trial. Lancet 2013;381:29-39. 